\title{
Etnografia przestrzeni miejskiej. Znaczenia nadawane sacrum i dziedzictwu ulicy Grodzkiej w Krakowie
}

\section{Abstract \\ Etnography of the City Space: Meanings of the Sacred and Heritage Related to Grodzka Street in Kraków}

This paper analyses and interprets field work material collected during ethnographic research on various understandings of heritage and the sacred associated with Grodzka Street in Kraków. The research was designed as part of the preparation for the exhibition Maps of the city: Heritages and the sacred within Kraków's cityscape. This exhibition was organized by the HERILIGION project team and opened to public in 2017. The author reveals some ethnographic background of the exhibition drawing on anthropological exploration of a particular street. Grodzka Street, located in the heart of the Old Town in Kraków, is part of a UNESCO heritage site - a space loaded with various nationally and locally shaped understandings of heritage. Using selected examples of the street's sacred sites and tourist attractions, as well as narratives collected among Kraków's inhabitants, the author presents the city space as a multivocal palimpsest.

Keywords: heritage, sacrum, ethnography of street, Kraków, Grodzka Street

\section{Wprowadzenie}

Ulica Grodzka, wraz z zabytkowymi budowlami położonymi wzdłuż obu jej pierzei, jest częścią tętniącego życiem turystycznym centrum Krakowa. Będąc elementem Starego Miasta, które zostało wpisane w roku 1978 na Listę obiek- 
tów światowego dziedzictwa $\mathrm{UNESCO}^{1}$, stanowi istotną przestrzeń oznaczoną na podróżniczych mapach i ustawicznie wymienianą jako obowiązkowy punkt programu zwiedzania miasta. Informacje na jej temat znajdują się w obszernych fragmentach przewodników po Krakowie, odszukamy je zarówno w tych najstarszych, jak i najnowszych publikacjach. Wzdłuż Grodzkiej biegną dwa ważne turystyczne szlaki - Trasa Uniwersytecka i Droga Królewska, zobaczyć można przykłady architektury sakralnej, takie jak kościół św. św. Piotra i Pawła, kościół św. Andrzeja czy kościół św. Idziego, i świeckiej, np. Arsenał Królewski, Collegium Broscianum czy Collegium Iuridicum. Ulica Grodzka może być postrzegana jako część polskiego dziedzictwa, rozumianego w kategoriach dziedzictwa materialnego, dobra kultury, zabytku (Kowalski 2013: 35-45), które jest prawnie ustanowione i chronione instytucjonalnie. Stanowi ono, jak twierdzi Jacek Purchla, „wyróżnik tożsamości miasta”, „towar” oraz „atrakcyjny zasób i czynnik rozwoju”, przynosi lokalnej społeczności korzyści i uprawomocnia znaczenie Krakowa jako ważnego punktu na mapie współczesnej Europy (Purchla 2005: 57).

Pierwsze skojarzenia, jakie nasuwają się na temat tej przestrzeni, to wrażenie, że zjawiska związane z turystyką całkowicie ją zdominowały. Jakie inne wymiary dziedzictwa można odkryć, zaglądając za fasady tego, co widoczne przy powierzchownym oglądzie centrum miasta? To właśnie stanowiło przedmiot zainteresowania antropologów, którzy w ramach projektu HERILIGION zostali zaangażowani do przeprowadzenia etnograficznego rozpoznania obrazu ulicy Grodzkiej ${ }^{2}$. Interesowało nas to, co nieoczywiste, ukryte, co stanowi osobiste postrzeganie

1 Więcej informacji dostępnych na stronie http://www.unesco.pl/kultura/dziedzictwo-kulturowe/swiatowe-dziedzictwo/polskie-obiekty/ (dostęp: 08.01.2018).

2 Badania dotyczące ulicy Grodzkiej w Krakowie przeprowadzono w okresie od stycznia do maja 2017 roku. Stanowiły one element prac polskiego zespołu międzynarodowego konsorcjum HERILIGION (The heritagization of religion and the sacralization of heritage in contemporary Europe), którego liderem jest prof. Oscar Salemink z Uniwersytetu Kopenhaskiego, a kierownikiem polskiego projektu dr hab. Anna Niedźwiedź z Uniwersytetu Jagiellońskiego. Ten fragment badań był bezpośrednio związany z przygotowywaniem wystawy „Mapy miasta. Dziedzictwa i sacrum w przestrzeni Krakowa”, której pomysłodawczynią i kuratorką była Anna Niedźwiedź, autorkami scenariusza członkinie polskiego zespołu HERILIGION: Anna Niedźwiedź, Monika Golonka-Czajkowska, Kaja Kajder, Magdalena Kwiecińska (wystawę eksponowało Muzeum Etnograficzne im. S. Udzieli w Krakowie w okresie: 18 listopada 2017-18 lutego 2018). Prace etnograficzne związane z ul. Grodzką koordynowała Kaja Kajder (która też przygotowała kwestionariusz badawczy) pod naukową opieką Anny Niedźwiedź. Materiał etnograficzny, na którym opiera się niniejszy tekst, zebrali wykonawcy projektu HERILIGION: Kaja Kajder oraz pracownicy pomocniczy: Bartosz Arkuszewski, Alicja Baczyńska-Hryhorowicz, Alicja Soćko-Mucha. Wszystkie materiały zostały przekazane do archiwum grantu. Konsorcjum HERILIGION działa w ramach programu HERA Uses of the Past (2016-2019) i jest finansowane przez sieć HERA, NCN, AHRC, FCT, DASTI, NWO oraz Komisję Europejską w programie Horyzont 2020 na podstawie umowy nr 649307, a jego polska część jest realizowana w Instytucie Etnologii i Antropologii Kulturowej na Wydziale Historycznym Uniwersytetu Jagiellońskiego. 
miejskiego sacrum ${ }^{3}$ i dziedzictwa. Szersze potraktowanie terminu „dziedzictwo”, rozumianego jako zjawisko dyskursywne i za podejściem konstruktywistycznym jako proces (Bendix 2009; Kowalski 2013), pozwoliło na prześledzenie zjawisk związanych z zagadnieniami:

- co jest postrzegane w kategorii dziedzictwa i jakie znaczenia są z nim wiązane?

- jakie jest indywidualne podejście do miejsc uznawanych w dyskursie oficjalnym za dziedzictwo?

- jak zmienia się w zależności od perspektywy postrzeganie sakralności/świeckości danych przestrzeni? Gdzie przebiegają granice tego, co święte/ świeckie, i gdzie znajdują się przestrzenie dla nich wspólne?

- jakie działania podejmują osoby związane z przestrzeniami uznanymi za dziedzictwo lub jak same to dziedzictwo kształtują?

Tak zakreślone rozważania nad tym, co uznawane jest za dziedzictwo i jak dziedzictwo jest konstruowane (heritagization) w odniesieniu do miejsc, przedmiotów i praktyk związanych z religią, nawiązują m.in. do koncepcji Birgit Meyer i Marleen de Witte. We wprowadzeniu do jednego z numerów czasopisma „Material Religion. The Journal of Objects, Art and Belief”, który był poświęcony relacji pomiędzy konceptem dziedzictwa a sacrum, autorki wskazywały, że chociaż dziedzictwo odnosi się do przeszłości, to nie jest wszystkim, co z przeszłości dziedziczymy. Jest tym, co zostało na różne sposoby ustanowione jako dziedzictwo i wpisane do kanonu, jednocześnie uzyskując dodatkową, często nową wartość. Meyer i de Witte zwracają uwagę, że dwa procesy, które mają miejsce na pograniczu dziedzictwa i religii, są szczególnie interesujące dla naukowej refleksji. Pierwszym byłoby rozpoznawanie i uznawanie za dziedzictwo tego, co religijne, co związane $\mathrm{z}$ kategorią sacrum. Drugim byłby proces sakralizacji dziedzictwa, a więc nadawania mu rangi „świętości”, która nie musi być i często nie jest związana z jego funkcją religijną, ale $\mathrm{z}$ wartościami, jakie są mu przypisywane (Meyer, de Witte 2013: 274-280).

\section{Etnografia ulicy}

Biegnąca od południowo-wschodniej części Rynku Głównego do skrzyżowania ulic Stradom, Św. Gertrudy i Bernardyńskiej ulica Grodzka jest jedną z najstar-

${ }_{3}^{3}$ Sacrum w kontekście badań nad dziedzictwem postrzegane było przez nas jako zjawisko dynamiczne i płynne, zależne od ludzkiego doświadczania i wartościowania. Jak pisał Michał Buchowski: „Datujący się od XIX w. pogląd, że «sacrum» i "profanum» oraz ich wzajemna opozycja mają charakter uniwersalny i że za ich pomocą da się definiować wszelkie zjawiska religijne, oraz idea utożsamiająca «sacrum» z religią, zostały pod koniec wieku podważone" (Buchowski 2005: 226). Takie rozumienie kategorii sacrum zbliżone jest do koncepcji „płynnego sacrum”, mającego być elementem charakteryzującym społeczeństwa ponowoczesne. 
szych dróg Krakowa. W przeszłości stanowiła część wczesnośredniowiecznego szlaku handlowego. Jej powstanie łączone jest z podgrodziem i osadą nazywaną Okołem, a także z lokacyjnym Krakowem. Ulica przez wieki ulegała rozmaitym przekształceniom, do dziś pozostaje jedną z głównych arterii w obrębie Starego Miasta $^{4}$. Należy do Drogi Królewskiej, jak nazywana jest od lat 60. trasa turystyczna biegnąca od placu Matejki na Wawel. Jak podaje Encyklopedia Krakowa, Via Regia jest „najatrakcyjniejszą w Kr.[akowie] trasą turyst.[yczną], przy niej znajduje się największa liczba zabytków o charakterze artyst.[ycznym] i historycznym" (Encyklopedia Krakowa 2000: 167). Z uwagi na to bogactwo niemożliwe byłoby opisanie wszystkiego, co przynależy do obszaru ulicy Grodzkiej i jest określane mianem dziedzictwa. Ze względu na to, że opisywane przeze mnie prace związane z ulicą Grodzką były ściśle podporządkowane wstępnemu scenariuszowi wystawy „Mapy miasta. Dziedzictwa i sacrum w przestrzeni Krakowa” oraz założeniom projektu naukowego HERILIGION, otrzymaliśmy określone przez kierownika projektu (Annę Niedźwiedź) wytyczne wskazujące na dwa obszary zainteresowań. Z jednej strony prace zespołu skupione były na czterech miejscach kultu religijnego: Domie modlitwy błogosławionej pamięci Mordechaja Tignera, kościele św. św. Piotra i Pawła, kościele św. Andrzeja wraz z klasztorem klarysek oraz kościele św. Marcina. Z drugiej strony mieliśmy za zadanie dokonanie etnograficznej eksploracji „wewnętrznego życia ulicy” i zrozumienia, jak ten turystyczny trakt jest postrzegany przez mieszkańców Krakowa, zwłaszcza osoby blisko związane z ulicą Grodzką. Tak zakreślone zadania wraz z zawężonym na potrzeby planowanej wystawy obszarem stanowiły przedmiot dyskusji i podlegały negocjacji w zespole badawczym. Ograniczenia rodziły ważne pytania dotyczące tego, czym ów „teren ulicy Grodzkiej” jest dla antropologa, jak badać ulicę i co badać w jej obrębie ${ }^{5}$, co włączyć w nasze działania, co pominąć. Pojawiające się dylematy w czasie trwania projektu uświadamiały nam, że etnografia ulicy może być jedynie próbą fragmentarycznego opisu doświadczanej rzeczywistości. Mozaika miejsc, tras, przede wszystkim zaś opowieści ludzi związanych z ulicą Grodzką pokazuje, jak złożoną tkanką jest miejska przestrzeń, a odnalezienie się w niej musi wykorzystywać mechanizmy selekcji i wyboru.

$\mathrm{Na}$ niniejszy tekst składa się analiza i interpretacja materiałów, które były zbierane przez czwórkę etnografów zaangażowanych w badania terenowe w okresie od stycznia do marca 2017 roku. Z uwagi na „bliskość” terenu (Kraków jest obecnym miejscem zamieszkania każdej osoby z tej grupy) oraz wciąż nurtujące nas

${ }^{4}$ Informacje na temat ulicy Grodzkiej w Encyklopedii Krakowa, por. hasła Grodzka, Okół, Droga Królewska. Patrz również Z. Górka, Ulica Grodzka jako jedna z głównych ulic krakowskiej dzielnicy staromiejskiej, [w:] B. Domański, W. Kurek (red.), Gospodarka i przestrzeń: Prace dedykowane Profesor Danucie Ptaszyckiej-Jackowskiej, Kraków, s. 113-122.

${ }^{5}$ Uwaga zespołu badawczego, ze względu na realizowany projekt, skierowana była na „dziedzictwo" i sacrum. Poprzez te kategorie postrzegaliśmy przestrzeń ulicy Grodzkiej. Te same zjawiska mogą być analizowane i interpretowane za pomocą użycia zupełnie innych kategorii, jak np. „nie-miejsca” Marca Augégo (2010) lub „miejsca pamięci” Pierre’a Nory (2009). 
pytania kolekcjonowaliśmy materiały „punktowo”. Fazę pierwszą poświęciliśmy na obserwacje, przemierzaliśmy przestrzeń ulicy tam i z powrotem, spacerowaliśmy, przyglądaliśmy się, braliśmy udział w różnych wydarzeniach i staraliśmy się odnaleźć swoje miejsce w skomplikowanej sieci znaczeń, w jaką się zanurzyliśmy. W tym czasie spisywaliśmy także własne wspomnienia, emocje i osobiste odczucia związane z ulicą Grodzką, które stanowily przedmiot dyskusji, podczas częstych zebrań zespołu.

W trakcie pierwszych spotkań dzieliliśmy się obawami dotyczącymi samej przestrzeni badań. Postrzegaliśmy ją jako bezosobową część turystycznego życia miasta, gdzie to, co prywatne, indywidualne, było dla nas niewidoczne i trudne do wyobrażenia. Dobrze te wątpliwości oddaje notatka w jednym z dzienników badawczych. Dzienniczki zawierają zapisywane na bieżąco w terenie spostrzeżenia i refleksje każdego z etnografów.

Przeszłam ulicą Grodzką kilka razy, starając się nie myśleć jeszcze o badaniach, jakie mamy w planie. To, co mnie uderza, to różnica pomiędzy Grodzką „fasadową”, Grodzką, którą przechodzę co jakiś czas, nie przywiązując szczególnej uwagi do mijanych przestrzeni i miejsc, a tą, jaka może się przed nami już niedługo ujawni w obserwacji. Mam silne uczucie odcięcia od „ludzkiego" wymiaru ulicy, czuję się trochę jak turysta, a trochę jak typowy mieszkaniec Krakowa, który zajęty swoimi sprawami, w pośpiechu, nie zwraca uwagi na otaczającą go przestrzeń. O badaniach na Grodzkiej myślę z lekką obawą, zastanawiam się, jak ciężkie w praktyce okaże się analizowanie miejsc dobrze znanych, będących częścią mojego miasta, których do tej pory nie traktowałam jako potencjalnego obiektu namysłu antropologicznego.

Z dystansu mogę ocenić, że powodem trudności i niepokoju była bliskość Grodzkiej (geograficzna i mentalna) oraz poczucie, że wszyscy znamy ją aż za dobrze, z życia codziennego i spacerów po mieście. W następnych tygodniach rozpoczął się proces defamiliaryzacji oczywistości (Brocki 2011: 74) przestrzeni - zaczęliśmy odkrywać nieznane nam miejsca, nowe wymiary tych opatrzonych i powiązane z nimi cudze narracje. Prowadzone regularnie dzienniczki badań stanowią ciekawy materiał umożliwiający analizę zmieniającego się podejścia. To, co jest widoczne w notatkach i co ujawniło się podczas dyskusji w grupie, to przesunięcie zainteresowania na mieszkańców i konieczność wyeksponowania punktu widzenia osób, którym Grodzka jest w jakimś stopniu bliska, którzy uważają ją za „swoją przestrzeń” lub „dom”.

I wtedy wreszcie dostrzegam to, czego nie dostrzegałam wcześniej: mieszkania. Zupełnie prywatnych ludzi, którzy na Grodzkiej nie pracują, sprzedają, zarabiają, zwiedzają, studiują, ale zwyczajnie i codziennie żyją. Oczywiście, zawsze wiedziałam, że takie mieszkania są. Ale nigdy ich nie zauważałam. Teraz, po zmroku jest to o wiele łatwiejsze - widać, gdzie świecą się światła. Chodzę po ulicy z głową zadartą do góry i obserwuję: liczę ilość świateł w każdej kamienicy, staram się dojrzeć, czy widać coś zza zasłonki, rozważam, czy to mieszkanie, czy może hostel. Szczególnie urzekają mnie okna jednego mieszkania, wręcz wypełnione okazałymi, doniczkowymi kwiatami. Ten widok bardzo kojarzy mi się ze zwyczajną codziennością, która z kolei kontrastuje z wizerunkiem Grodzkiej z mojej głowy - miejsca wiecznej rozrywki, pośpiechu, poszukiwania wyjątkowości. 
Odnajduję we własnych notatkach podobne spostrzeżenie, pochodzi ono z dnia przemarszu Orszaku Trzech Króli, którego trasa biegnie z Wawelu i dalej wzdłuż Grodzkiej, w stronę Rynku Głównego.

[...] zwalniamy dopiero na linii początku ulicy, zaczyna się robić weselej, wiele osób śpiewa kolędy. Pochód jest kolorowy, wszędzie widać poprzebieranych uczestników, dzieci w królewskich strojach, aniołki, krakowiaków, którzy idą z nami. [...] Zauważam kobietę wychodzącą ze sklepu, która spogląda, jak mi się wydaje, z pewną niechęcią na cały pochód i zapala przed sklepem papierosa. Zaczynam zastanawiać się, czy słychać śpiewanie kolęd i gwar tłumu w mieszkaniach położonych przy Grodzkiej?

W jednej z rozmów na pytanie zadane o „drugie życie ulicy” rozmówczyni poprawiła badacza na formę „pierwsze życie”. Tę korektę uznaję za bardzo znaczącą, ponieważ pokazuje, jak ważna jest perspektywa rozmówcy i że starając się zagłębić w to „inne” życie, trzeba się jednocześnie nauczyć postrzegać je jako pierwszoplanowe.

Druga faza projektu polegała na uzupełnieniu naszych dotychczasowych działań o rozmowy przeprowadzone z ludźmi, dla których ulica Grodzka była miejscem zamieszkania, pracy, nauki lub parafii, z którą byli związani. W efekcie powstało ponad dwadzieścia pogłębionych wywiadów etnograficznych. Oprócz wywiadów wiele obserwacji znalazło odzwierciedlenie we wspomnianych dziennikach badawczych. Zebraliśmy także materiał wizualny w postaci fotografii przekazanych przez osoby, z którymi się spotykaliśmy, oraz dokumentów kolekcjonowanych w terenie (ulotki, reklamy, obrazki) lub wytwarzanych (zdjęcia, nagrania wideo).

Podczas spotkań finalizujących projekt omówiliśmy kwestie zmiany naszego postrzegania przestrzeni Grodzkiej, która stała się dla nas skomplikowaną siecią doświadczeń, ludzi, miejsc, wydarzeń. Artykuł stanowi przedstawienie tych kwestii, które być może pozwolą wniknąć w głębszy wymiar tego, co było tematem projektu, a więc zagadnienia, czym jest „dziedzictwo” oraz jakie relacje mogą zachodzić pomiędzy wyobrażeniami na jego temat a sakralizacją przestrzeni. Omówione poniżej miejsca: Dom modlitwy błogosławionej pamięci Mordechaja Tignera i kościół św. św. Piotra i Pawła stanowią dwa wybrane przykłady obiektów kultu religijnego, które są ulokowane przy ulicy Grodzkiej. Ich przestrzenie, sposoby ich postrzegania i odbiór przywołują różne relacje wobec wyobrażeń sacrum, przeszłości czy dziedzictwa. W kolejnej części artykułu nastąpi zarysowanie kontekstu badań, ze szczególnym zwróceniem uwagi na to, co w wypowiedziach rozmówców uzyskało osobisty wymiar. Rozwinięciem wątku jest materiał etnograficzny ukazujący rozmaite sposoby rozumienia terminu „dziedzictwo”. 


\section{Przestrzeń zapomniana}

W oficynie kamienic przy ulicy Grodzkiej 28/30 znajduje się wybudowany na początku XX wieku Dom modlitwy błogosławionej pamięci Mordechaja Tignera. Miejsce związane z życiem religijnym społeczności żydowskiej w dwudziestoleciu międzywojennym, obecnie prawdopodobnie pozostające $w$ ruinie. Prawdopodobnie, ponieważ nie ma do niego dostępu. Brama, przez którą można było dostać się na zaplecze budynków, przez ostatnie lata pozostawała zamknięta na kłódkę, a niedawno w jej miejscu pojawił się kolejny sklepik, obok znajdujących się już na parterze sklepu obuwniczego, cukierni i stoiska z pamiątkami. Zastanawiający jest przede wszystkim nie tyle stan faktyczny budowli, ile raczej nieobecność tej opuszczonej przestrzeni w świadomości mieszkańców miasta. Wielu rozmówców pytanych w czasie prowadzonych przez nas badań nie wiedziało o istnieniu takiego miejsca. Jedynie nieliczni znali jego historię lub potrafili wskazać, gdzie dokładnie się znajdowało. Nierzadko to my - etnografowie zadający pytanie o dom modlitwy - stanowiliśmy źródło informacji dla innych. Ponieważ próby kontaktu $\mathrm{z}$ właścicielem nie powiodły się, a rozpytywanie osób w bezpośrednim sąsiedztwie nie dawało rezultatów, konieczna okazała się zmiana strategii, porzucenie planów zobaczenia wnętrza modlitewni i próba rekonstrukcji przestrzeni w oparciu o dokumenty, fotografie i opowieści.

$Z$ wizualnych świadectw ${ }^{6}$ tego miejsca wyłania się obraz rozpadu i zniszczenia. Temat złego stanu budynku i jego nieobecności na mapie współczesnego miasta pojawiał się $\mathrm{w}$ rozmowach $\mathrm{z}$ tymi krakowianami, którzy o domu modlitwy przy Grodzkiej słyszeli i interesowali się wielokulturową oraz wieloreligijną historią Krakowa. Jedna $\mathrm{z}$ takich osób w rozmowie z etnografem wyznała:

Szkoda mi jednego miejsca, które jest, ale nie istnieje, tzn. synagogi przy ul. Grodzkiej. Że kto tam wejdzie, na przykład, do sklepu takiego indyjskiego i uda mu się zerknąć na zaplecze, to są takie... części, jeszcze pozostałości na ścianach malowideł. Natomiast wstydliwie zakrywane. I to miejsce nie istnieje tak naprawdę w świadomości mieszkańców ani takiej turystycznej.

Niektórzy wskazywali na turystyczny potencjał miejsc związanych z historią krakowskich Żydów. Kraków wraz ze zmianami i rewitalizacją dzielnicy Kazimierz (Murzyn-Kupisz, Purchla 2008) oraz w trakcie analogicznego procesu w Podgórzu (zob. np. Niedźwiedź 2007) jest jednym ze szczególnych miejsc na mapie pielgrzymek i wycieczek związanych z kulturą żydowską. Na nieobecność podobnych upamiętnień w obrębie centrum wskazywali autorzy albumu towa-

6 Pierwsze fotografie wnętrza domu modlitwy, poza tymi, które są dostępne w Internecie, udało mi się zobaczyć dzięki uprzejmości Jana Jagielskiego w archiwum Żydowskiego Instytutu Historycznego. W segregatorach zawierających zdjęcia miejsc związanych z żydowskim Krakowem, obok bogato udokumentowanych najważniejszych synagog i ulic Kazimierza oraz przestrzeni Podgórza, znaleźliśmy jedynie trzy fotografie będące zapisem stanu budynku z roku 1963 i jedną z roku 2005 - adnotacja do niej brzmi „obecnie zrujnowana”. 
rzyszącego wystawie Świat przed katastrofą (Purchla, Skotnicki 2007: 5). Również Agnieszka Bisaga-Widacka pisała w 2006 roku na łamach czasopisma „Kraków”:

Stan obecny świątyni wzbudza dość ponure refleksje - efektowny przykład wielowiekowej tradycji architektonicznej niezmiennie od trzydziestu lat oczekuje swego nieuchronnego losu. [...] Rudera, która przy odrobinie dobrej woli mogłaby stać się atrakcją turystyczną miasta i wystawić chlubne świadectwo wielokulturowości jego mieszkańców, obnaża w całej ostrości naszą obojętność.

Kiedy spotkałam się z nią ponad dekadę po opublikowaniu artykułu, jej opowieść połączona $\mathrm{z}$ pokazem zdjęć dokumentujących niedostępne i zrujnowane wnętrza pozwoliła mi wyobrazić sobie tę przestrzeń. O współczesnej sytuacji tego miejsca pani Agnieszka opowiadała:

Strasznie smutne miejsce, [...] najgorsze jest to, że takie zapomniane od Boga i od ludzi. Takie ładne i takie niewykorzystane. Czuje się Pani tam okropnie smutno, że to świat, który się skończył bardzo dawno temu i bezpowrotnie i jest nie do odbudowania. I jest Pani smutno z tego powodu, że żyje Pani wśród kulturalnych ludzi i po prostu jest niemoc... jakieś fatum.

Chociaż można odnieść wrażenie, że czas dla domu modlitwy Tignerów zatrzymał się od momentu jego zamknięcia z początkiem II wojny światowej, upływające lata zapewne pogłębiają poczynione już zniszczenia. Dziedzictwo nie może istnieć bez pamięci, jest elementem przeszłości, który jest uznawany przez pewne grupy za warty upamiętnienia i przypominania (Sather-Wagstaff 2015: 191). I pomimo zauważalnego potencjału, jaki posiada ta przestrzeń jako miejsce pamięci, zachodzi w tym przypadku proces, który możemy określić w kontekście pamięci zbiorowej jako zapominanie (Connerton 2014) lub wymazywanie (Jałowiecki 2009: 12).

\section{Kościół i Panteon}

Drugi przykład, który wybrałam, aby ukazać rozmaite sposoby funkcjonowania przestrzeni sakralnych przy ulicy Grodzkiej, to kościół św. św. Piotra i Pawła. Ze względu na swoją charakterystyczną architekturę porównywany jest do macierzystego kościoła jezuitów Il Gesu w Rzymie. Jedna z rozmówczyń wspomniała, „jak siedziałam w «Bonie» [krakowska kawiarnia] na Kanoniczej i z koleżanką piłam wino, patrzyłyśmy na kościół Piotra i Pawła i mówię: I po co jechać do Włoch? Można się napić wina tutaj. [śmiech] Bo to taka włoska architektura”. Przyglądając się funkcjonowaniu kościoła wewnątrz, można dostrzec jego turystyczny charakter. Przy wejściu przyciąga uwagę maszyna, w której sprzedawane są pamiątkowe monety, zwiedzanie ułatwiają dostępne do wypożyczenia audioprzewodniki, a przy zejściu do krypty należy uiścić „dobrowolną ofiarę”, stanowiącą coś na kształt biletu. Turyści mogą się też wybrać na regularnie organizowane koncerty 
muzyki klasycznej. Współcześnie pewien stopień muzealizacji wnętrz kościołów to zjawisko powszechne $\mathrm{w}$ wielu europejskich miastach, $\mathrm{z}$ tego powodu obecność turystów jest elementem stałym. Jednocześnie miejsce jest używane przez Parafię Rzymskokatolicką pod wezwaniem Wszystkich Świętych, co przekłada się na współdzielenie przestrzeni przez wiernych i turystów, często w tym samym czasie. Tak właśnie było, kiedy wybrałam się na „święcenie pokarmów” podczas Wielkanocy 2017 roku. Wokół swobodnie przemieszczały się małe grupy i pojedynczy zwiedzający, z zaciekawieniem przystając w czasie krótkiej uroczystości. Było nas zaledwie kilkanaście osób, zgrupowanych przez księdza w nawie bocznej kościoła. Frekwencja niewielka, być może częściowo związana z popularnością uroczystości w innych lokalizacjach, np. w kościele Mariackim. Moją uwagę zwrócił kontakt księdza z wiernymi, którzy po zakończeniu zatrzymywali się na rozmowę i wymianę życzeń. Właśnie w takich momentach ujawnia się osobisty wymiar tego miejsca, które pełniąc funkcję sakralną, cementuje poczucie wspólnoty grupy.

Znajdujący się w podziemiach kościoła Panteon Narodowy ${ }^{7}$ został uroczyście otwarty 27 września 2012 roku. Już sama nazwa „panteon” odnosi do religijnego kontekstu miejsca, które chociaż mieści w sobie grobowce osób świeckich, uzyskuje swój sakralny wymiar właśnie dzięki odwołaniu do wspólnej historii i tradycji. Podczas przemowy towarzyszącej inauguracji działania Panteonu prezes Fundacji Marek Wasiak powiedział: „To powód do dumy, że temu przedsięwzięciu towarzyszy tak wiele osób rozumiejących szczególną misję, jaką przychodzi wypełniać temu miejscu, rozumiejących powinność naszego miasta wobec dziedzictwa naszych ojców" (Pagacz-Moczarska 2012: 56-57). W przyszłości pochowani tutaj mają być wielcy polscy artyści i uczeni. Sam Panteon Narodowy to trzecie takie miejsce pamięci w Krakowie, ,jest kontynuacją dwóch wcześniejszych kra-

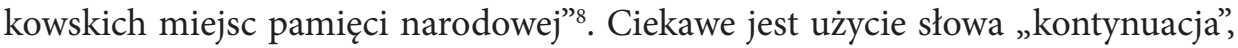
wskazującego na mityczną linię, która wywodząc się od polskich królów (Groby Królewskie na Wawelu), poprzez tych, których prochy spoczywają w Krypcie Zasłużonych w kościele oo. Paulinów na Skałce, buduje wspólnotę narodową wraz ze współczesnymi i tymi, którzy będą po nich. Również tutaj odnajdziemy ślady osobistego użytkowania tej przestrzeni. Na grobowcu Sławomira Mrożka, pochowanego w 2013 roku, położono wiązankę, a obok kartkę informującą, że rodzina

Pomysłodawcą utworzenia Panteonu Narodowego jest profesor Franciszek Ziejka, będący przewodniczącym Rady Fundacji Panteon Narodowy, utworzonej w 2010 roku. Do Rady Fundacji należą między innymi rektorzy polskich uczelni, Metropolita Krakowski i Prezes Polskiej Akademii Umiejętności. Więcej na temat działalności Fundacji na stronie: http://www.panteonnarodowy.org/ (dostęp: 08.01.2018).

${ }^{8}$ Cytat pochodzi z artykułu: Sławomir Mrożek spocznie w Panteonie Narodowym, wyborcza. pl/1,75410,14460906,Slawomir_Mrozek_spocznie_w_Panteonie_Narodowym.html, (dostęp: 08.01.2018). Sformułowanie „kontynuacja idei Grobu Zasłużonych” pojawia się również na stronie Fundacji Panteonu Narodowego: http://www.panteonnarodowy.org/strona/idea-i-historia (dostęp: 08.01.2018). 
prosi o nieusuwanie pozostawionych kwiatów. Ujawnia się tutaj podwójna rola, jaką odgrywa to miejsce, $z$ jednej strony mamy grób przedstawiciela narodowych artystów, którzy zostali pochowani „niezależnie od przekonań politycznych i wyznawanej wiary”, ale ze względu na zasługi dla kraju i wspólnoty, z drugiej zaś strony mamy osobiste, rodzinne „miejsca pamięci”.

Datę otwarcia Panteonu Narodowego wyznaczono na 400. rocznicę śmierci księdza Piotra Skargi nieprzypadkowo - postać jest w Krakowie otoczona żywym kultem. Zwyczaj zanoszenia do niego modlitw i życzeń opisuje jeden z członków naszej grupy:

W pierwszej kaplicy na prawo od ołtarza (patrząc wprost na ołtarz) stała trumna ze szczątkami Skargi, na której rozłożono flagę polską. Była tabliczka informująca o tym, że mimo iż Skarga jest Sługą Bożym, to istnieje tradycja składania mu próśb (zarówno tutaj w koszyczku, ale zauważyłem, że na dole w katakumbach również wtyka się kartki pod jego sarkofag).

Co ważne, adresowane do turystów działania nie ominęły również samej krypty, gdzie znajdują się szczątki ks. Piotra Skargi. Jak dalej notuje etnograf, „otwarte było wejście do katakumb i tam też prowadził przewodnik audio. Tam należało przystanąć przy krypcie Skargi, [na nagraniu] pojawił się nowy głos - ducha Piotra Skargi, który opowiadał o sobie. Tylko ta krypta była omówiona przez przewodnika”. Z powyższych przykładów wyłania się obraz wielowymiarowej przestrzeni, w której zawierają się zarówno elementy dziedzictwa religijnego i narodowego, ale również osobistego, jak miejsce pamięci rodzinnej i miejsce żywego kultu, który związany jest $\mathrm{z}$ duchowym życiem wiernych. W funkcjonowaniu kościoła św. św. Piotra i Pawła widoczne są też procesy, o których piszą Meyer i de Witte, czyli z jednej strony uznawanie za dziedzictwo tego, co w swej pierwotnej funkcji związane było (jest) przede wszystkim ze sferą sacrum, z drugiej zaś postępujące zjawisko sakralizacji dziedzictwa (Meyer, de Witte 2013: 277). Proces pierwszy może powodować zsekularyzowanie form religijnych, co ma miejsce, kiedy świątynia staje się obiektem turystyki nastawionej na doświadczanie architektury czy poznawanie historii. Z kolei sakralizacja dziedzictwa dobrze widoczna jest na przykładzie Panteonu, który będąc miejscem pochówku zasłużonych Polaków, umacnia poczucie wspólnoty narodowej i staje się miejscem kultu przodków.

\section{Osobiste wymiary przestrzeni}

$\mathrm{W}$ przeprowadzonych przez nas rozmowach $\mathrm{z}$ osobami związanymi na co dzień z ulicą Grodzką odnaleźć można wypowiedzi świadczące o dużym emocjonalnym przywiązaniu rozmówców do użytkowanej przestrzeni. Pozytywne wartościowanie historycznego wymiaru tej części Drogi Królewskiej było kojarzone ze znaczeniem, jakie może mieć ona dla narodowej wspólnoty: „jako że Grodzka jest jedną z najważniejszych ulic Krakowa, a Kraków jest, jak wiado- 
mo, najważniejszym miastem Polski [...] to Grodzka jest absolutnie kluczowym [...] elementem dziedzictwa i świadomości Polaków jako Polaków”. Przekonanie o unikatowości ulicy było łączone również z jej wymiarem estetycznym, co jest widoczne w opinii jednego z rozmówców: „dla mnie perspektywa [...] od strony Rynku, jak patrzę w ulicę Grodzką, to jest najpiękniejsza perspektywa krakowska”. Osoby, z którymi rozmawialiśmy, wskazywały swoje ulubione miejsca w obrębie tej przestrzeni i osobiste preferencje co do lokalizacji, z których lubią ją obserwować. Najczęściej wymieniane były punkty widokowe na całą ulicę, pierwszy od strony kościoła św. Wojciecha, drugi od strony kościoła św. Idziego, oraz perspektywa z placu Marii Magdaleny, która umożliwia spoglądanie na fasadę kościoła św.św. Piotra i Pawła. W zebranych wypowiedziach atrakcyjność Grodzkiej oceniana była wyżej niż inne miejskie przestrzenie, nie tylko w kontekście lokalnym, ale w skali europejskiej.

Osobisty wymiar ulicy Grodzkiej ujawnił się w szeregu narracji wspomnieniowych. Jeden z rozmówców opowiedział np. o sklepie z muszlami znajdującym się w Collegium Iuridicum: „jedno z moich najwcześniejszych wspomnień z dzieciństwa jest związane z tym budynkiem. [...] Pamiętam właśnie, jak byłem małym dzieckiem i zdarzało mi się tam przychodzić po muszle”. Inny zwrócił uwagę na nieobecny w przeszłości zakaz ruchu samochodowego: „to jest chyba takie najwcześniejsze wspomnienie z ulicą Grodzką, jakie mam. Siedzę w samochodzie i wyglądając przez okno, obserwuję całe tłumy ludzi”. Te pozornie mało znaczące wypowiedzi pozwoliły odtworzyć mentalną mapę ulicy Grodzkiej. Zainteresowanie zespołu badawczego podążało za doświadczeniami i uwagami rozmówców, którzy będąc uważnymi obserwatorami, potrafili wskazać i opisać procesy zmian, jakim podlegała ta przestrzeń. Można z nich odtworzyć historię pojawiających się i znikających lokali usługowych, ewolucję życia dwóch znajdujących się na tym obszarze parafii (rzymskokatolickiej Wszystkich Świętych, związanej z kościołem św. św. Piotra i Pawła, oraz ewangelicko-augsburskiej w kościele św. Marcina) czy przekształcenia, jakim uległy wydziały i kierunki Uniwersytetu Jagiellońskiego 9 . Opowieści, często uzupełnione komentarzem, poszerzyły naszą perspektywę do okresu ostatnich kilkudziesięciu lat. Dobrym przykładem może być wypowiedź

${ }^{9}$ Do Uniwersytetu Jagiellońskiego należą trzy ważne historyczne budynki przy ul. Grodzkiej: CB, CI, AW. Collegium Broscianum to budynek dawnego kolegium jezuickiego, który po kasacie zakonu pełnił rozmaite funkcje edukacyjne i administracyjne. W latach 1815-1846 znajdowała się tutaj siedziba Senatu Wolnego Miasta Krakowa. Obecnie budynek służy za siedzibę Wydziału Filozoficznego. Do Collegium Iuridicum w XV w. należał niezachowany do dziś kościół św. Marii Magdaleny. Obecnie powiązane z budynkiem jednostki to Instytut Historii Sztuki, Wydział Prawa i Administracji, Katedra Prawa Pracy i Polityki Społecznej. Dawny Arsenał Królewski został wzniesiony przy bramie Grodzkiej w 1533 r. przez Zygmunta I Starego. Po gruntownej przebudowie w XVII w. przez Władysława IV zaczął być nazywany jego imieniem. Obecnie związane z budynkiem jednostki to Katedra Literatury i Badań Kulturalnych, Wydział Polonistyki, Centrum Języka i Kultury Polski w Świecie oraz Katedra Międzynarodowych Studiów Polonistycznych. Zob. Encyklopedia Krakowa, hasła Collegium Broscianum, Collegium Juridicum, Arsenał Królewski. 
o wymianie i rekonstrukcji figur z ogrodzenia przed kościołem św. św. Piotra i Pawła, opatrzona opinią na temat gospodarki i sposobu pracy w okresie trwania poprzedniego ustroju politycznego w Polsce:

Te figury się zmieniały, w tym sensie, że [...] przecież przez ładnych parę lat ich nie było. Też nie potrafię określić, czy to było pięć czy dziesięć lat. Ale wtedy były takie te okresy, że, powiedzmy jak się coś zaczynało robić, no to w PRL-u nie szło szybko. I długie lata, pamiętam, w każdym razie dla mnie to były długie lata, nie było figur. Jak było, jak wróciły, no to było [...] dla mnie święto w pewnym sensie, bo wreszcie ten obraz tak się dopełnił.

Indywidualne narracje związane z biografiami rozmówców ujawniły również znaczenie Grodzkiej jako miejsca ważnych rodzinnych uroczystości, takich jak odbywające się w parafiach chrzciny czy śluby. Przestrzeń ulicy stanowiła scenerię dla oświadczyn, niedzielnych spacerów i towarzyskich spotkań mieszkańców miasta.

Wywiady dotyczące szerokiego spektrum osobistych doświadczeń obejmowały $\mathrm{z}$ jednej strony narracje o tym, jak mieszka się w położonych wzdłuż ulicy Grodzkiej kamienicach, z drugiej zaś opowieści o uczestniczeniu w corocznych procesjach i pochodach, takich jak Boże Ciało czy Orszak Trzech Króli. Wyłania się z nich obraz przeplatania się tego, co publiczne, z tym co prywatne, czasem nawet bardzo bezpośrednio i dosłownie, jak w tym wspomnieniu przywołanym w czasie dyskusji między rozmówcami:

R: Przemarsz Smoków jest co roku. W którymś roku był jeden taki duży smok, że głowa mu tu weszła, przez okno po prostu. Taki wysoki, wielki smok. [...] R2: Ale nam to nie przeszkadza, dlatego, że tu są grube mury i to jest ciche mieszkanie. R3: Na drugie piętro już te echa nie idą.

Grodzka jako droga jest użytkowana na wiele sposobów. Obok miejsca licznych uroczystości i obecności ruchu turystycznego stanowi czyjąś codzienną trasę do pracy, do sklepu czy do domu. Powtarzającą się w wypowiedziach kwestią były wynikające $\mathrm{z}$ tego niedogodności odczuwane przez rozmówców w postaci kłopotów z wejściem do lub wyjściem z danego miejsca, spóźnień czy problemów z przeprowadzką. Jak można wywnioskować z jednej z wypowiedzi, pospieszny sposób poruszania się części osób przemierzających Grodzką może być wskazówką, że osoba ta mieszka tu lub pracuje:

Nie wiem, jak się żyje na Grodzkiej, ale wiem, jak się pracuje. I wiem, jak się biegnie, śpieszy się do pracy, i przebija się przez tłumy, czasami naprawdę duże tłumy turystów, którzy w takim zupełnie zwolnionym tempie te ulice przemierzają. Uderza to, że to jest takie właśnie miejsce turystyczne. A my jesteśmy jednymi z niewielu osób, które się śpieszą, na tej ulicy.

Narracje ujęte w wywiadach tworzą polifoniczną i palimpsestową opowieść utkaną z wątków dotyczących ludzi, miejsc i tras wchodzących ze sobą w rozmaite relacje. Powyższe, szkicowo tylko zarysowane, osobiste wymiary doświadczania ulicy ujawniają skalę różnorodności tego, co może stanowić przedmiot etnograficznego opisu. Silnie widoczna fragmentaryczność wątków, pozostających 
niejako na marginesie zjawisk związanych z procesem postrzegania dziedzictwa Grodzkiej, stanowi dla nich ważny kontekst. Osoby, z którymi rozmawialiśmy w czasie badań, posiadają swoją indywidualną perspektywę, wynikającą z powiązań łączących je z przestrzenią, o którą pytaliśmy, co znajduje swoje odzwierciedlenie w tym, jak tę przestrzeń wartościują i jakie nadają jej znaczenia.

\section{Warianty rozumienia terminu „dziedzictwo" i przykłady użycia}

Kategoria dziedzictwa jest widoczna w dyskursach instytucjonalnych związanych $\mathrm{z}$ miejską przestrzenią Krakowa. Ujawnia się ona również w rozmowach z ludźmi wraz $\mathrm{z}$ jej potocznym rozumieniem i nadawanymi znaczeniami. $\mathrm{W}$ trakcie trwania projektu zadawaliśmy rozmówcom pytania, czym jest „dziedzictwo”. Interesowało nas, jak jest ono potocznie definiowane i jaki rozmawiające $\mathrm{z}$ nami osoby mają do niego stosunek. Wśród odpowiedzi pojawiło się wiele skojarzeń z tym, co zostało nam pozostawione przez przodków i co podlega obowiązkowi przekazania następnym pokoleniom: „dziedzictwo kojarzy mi się właśnie z tym, co otrzymaliśmy od... naszych ojców, dziadów, pradziadów itd. w tych pokoleniach, o co musimy się troszczyć - [...] najbardziej to chyba kojarzy mi się z patriotyzmem". Bardzo zbliżone rozumienie widoczne jest również w tym fragmencie rozmowy:

Dziedzictwo to jest wszystko to, co mamy... zostawione przez naszych przodków, to, co tworzymy teraz i co powinniśmy zachować dla innych, o tym powinniśmy pamiętać, dbać o to przede wszystkim, żeby to nie niszczało. To jest po prostu takie świadectwo naszego życia, naszej kultury, tego że jakąś kulturę posiadamy. Że jest to... Jesteśmy jakoś osadzeni w ciągu historycznym, a nie po prostu wzięliśmy się znikąd i odejdziemy w nic.

Parokrotnie pytania wywoływały wyliczenia zabytków miasta, w tym również tych, które znajdują się przy ulicy Grodzkiej. Obok potocznego rozumienia tego terminu w kategoriach dziedzictwa materialnego, uprawomocnionego wpisem na listę UNESCO, powodem mogło być także to, że część naszych rozmówców studiowała historię sztuki lub ochronę dóbr kultury. W jednym $\mathrm{z}$ wywiadów pojawia się komentarz do takiej sytuacji:

Nie wiem, czy mam prywatną definicję. Ja o dziedzictwie myślę... Ostatnio zwłaszcza zastanawiam się nad tym pojęciem w kategoriach prawnych. Pisałem tekst dotyczący pojęcia „zabytku” w polskim prawie, wyznaczania tego, ile coś musi mieć lat, żeby było zabytkiem. I... myślałem o relacjach oczywiście wtedy dziedzictwa do dóbr kultury, do zabytków... To jest jakieś takie bardzo, bardzo szerokie pojęcie, ja... bardziej czuję się osobą od zabytków niż od dziedzictwa, bo dziedzictwo to też kultura niematerialna, która nigdy nie była dla mnie tak interesująca jak kultura materialna, po prostu. W końcu jestem historykiem sztuki, a nie etnologiem [śmiech]. 
W cytowanych wypowiedziach pojawiają się wskazania na dziedzictwo materialne i niematerialne, łączone z pojęciami „świętości”, „wiary”, z tym, co związane $\mathrm{z}$ religią i jej materialnymi reprezentacjami:

[...] bo tym aspektem niematerialnym [dziedzictwa] jest wiara czy... może nie wierzenie, ale wiara i tradycja; oczywiście to potem też ma jakieś swoje materializacje, prawda? No bo tradycja, że jemy karpia na Wigilię, no dlaczego karpia, a nie... nie wiem - szczupaka? [...] Na tym... na tym nie zbudujemy tożsamości narodowej, ale razem do kupy, te wszystkie rzeczy, uzbierane tworzą tę tożsamość. A tak palcem na mapie Krakowa to [...] mapy tych materialnych miejsc dziedzictwa narodowego... Nie można dziś przyjechać do Krakowa i nie zobaczyć... tak jak w Rzymie nie można nie zobaczyć Watykanu, nie wiem, katakumb i Koloseum i... tak samo w Krakowie [...] nie można nie zobaczyć Wawelu.

Jeśli mi wolno tak luźno mówić [...] o skojarzeniach, to myślę, że takie zachowane dziedzictwo to są meble, talerze, krzesła, jakieś obrazy, które wiszą po domach, które nie spaliły się w czasie wojny, nie zostały wywiezione, zagrabione. To są tradycje domów, jak się piecze, że się piecze takie ciasto na niedzielę, albo co się podaje na obiad, jak się podejmuje gości. Taki zwyczaj bym zaliczył do tego dziedzictwa, tym dziedzictwem jest gościnność krakowian, bo to krakowianie przyjmują wiele tysięcy studentów, od wieków - do swoich domów. [...] Dalej wyliczając, powiedziałbym o tej masie, masie zabytków... Zamek i wszystkie skarby ruchome i nieruchome w tych wszystkich pałacach i muzeach, jakie są w Krakowie. To też jest fenomenalne, to też się zalicza do tego dziedzictwa. Tym dziedzictwem też jest - świętość. To jest miasto, w którym jest mnóstwo kościołów, nie wiem, porównywane z Rzymem. [...] To są ulice miasta, po których chodzili święci.

Wśród najczęściej wymienianych przykładów dziedzictwa niezwiązanego z miejscami kultu religijnego obok Wawelu pojawiał się Uniwersytet Jagielloński. Jedna z osób na pytanie o skojarzenie z terminem „dziedzictwo” rozpoczęła swoją wypowiedź od słów: „z pewnością tu wysuwa się na pierwsze miejsce Uniwersytet Jagielloński, no, może to banalne stwierdzenie, ale to jedna rzecz taka... kto wie, czy nie [naj]bardziej znana w Europie i na świecie, bo jest to uniwersytet bardzo istotny, który miał znaczenie, ma znaczenie". W innym wywiadzie osoba pracująca w Collegium Broscianum, opowiadając o funkcjonowaniu budynku, jak i społecznych interakcjach na dziedzińcu, zwróciła uwagę na to, ,że to jest dziedzictwo, które w dalszym ciągu żyje. Nie jest właśnie muzeum, nie jest umuzealnione", uznając to za zaletę. Ta sama rozmówczyni wyraziła również opinię, że użytkowanie tego typu przestrzeni jako miejsca pracy podnosi w pewien sposób prestiż pełnionej funkcji, jest nobilitujące ze względu na długą tradycję związaną $\mathrm{z}$ historią Uniwersytetu. Inna wypowiedź, tym razem na temat Collegium Iuridicum, powiela dokładnie te same wątki:

I podoba mi się też to, że jest użytkowany w taki sposób, a nie w inny, na przykład. [...] Bo to jest uczelnia, każdy może tam iść, każdy może się tam uczyć. [...] Więc myślę, że można to też jako część dziedzictwa [zaliczyć]... też dziedzictwa, no bo „Ujot”. No Jagielloński to też jest najstarszy uniwersytet, więc... On sam jest dziedzictwem, a co dopiero jego budynki, te budynki w Krakowie, które są jego częścią... 
Porównanie powyższych wypowiedzi odzwierciedla twierdzenie Rodneya Harrisona, że dziedzictwo dzisiaj jest szerokim, grząskim terminem i może zostać użyte do opisania wszystkiego. Autor dokonuje wyliczenia rzeczy zarówno materialnych (budynki, pomniki, miejsca pamięci), jak i niematerialnych (pieśni, festiwale, języki), mających różną skalę - od pejzażu po mały fragment kości - i status - od pałaców po zwykłe miejsca zamieszkania (Harrison 2013). Ta różnorodność definiowania dziedzictwa pokazuje jedną z jego charakterystycznych cech, jaką jest aprioryczność i wybiórczość (Kowalski 2013). Działania zinstytucjonalizowane częściowo kształtują postrzeganie tego, co ludzie włączają w zakres budowanych na własny użytek definicji, ale ulegają one również przekształceniom i są redefiniowane. Narracje wyłaniające się z wywiadów wskazują na silnie obecną osobistą perspektywę oraz akcentowanie tego, co same osoby definiujące uznają za ważne.

\section{Zakończenie}

Palimpsestowa i polifoniczna przestrzeń ulicy Grodzkiej dobrze ilustruje różnorodność, a także procesualny charakter tego, co i przez kogo za dziedzictwo jest uznawane. Znajduje tu potwierdzenie koncepcja, że „dziedzictwo jest formą posiadania przeszłości, kolekcją, a więc w konsekwencji wyborem" (Kowalski 2013: 19). Przedstawione $w$ artykule doświadczenia, obserwacje i wywiady mające stać się częścią wystawy opisującej współczesny Kraków (wraz z jego sacrum i dziedzictwami) obejmują zaledwie ułamek tego, co składa się na współczesne „życie” ulicy. Ten zdominowany przez osobiste narracje obraz, chociaż fragmentaryczny, pozwala zajrzeć za fasadę turystycznego centrum miasta. Uważne przyjrzenie się temu, co jest obecne w obrębie ulicy, a czego nie ma albo pozostaje niewidoczne, pozwala dostrzec historię Krakowa jako miasta wielokulturowego i wieloreligijnego. Ujawnia również świat skomplikowanych prywatnych relacji pomiędzy mieszkańcami, pracownikami, parafianami a przestrzenią miasta.

\section{Bibliografia}

Augé M.,

2010 Nie-miejsca. Wprowadzenie do antropologii hipernowoczesności, przeł. R. Chymkowski, Warszawa.

Bendix R.,

2009 Heritage between Economy and Politics: An Assessment from the Perspective of Cultural Anthropology, [w:] Intangible Heritage, eds. L. Smith, N. Akagwa, London, s. 253-269. 
Brocki M.,

2011 Problemy podstaw wiedzy antropologicznej: refleksje metodologiczne, [w:] Teren $w$ antropologii: praktyka badawcza we współczesnej antropologii kulturowej, red. T. Buliński, M. Kairski, Poznań, s. 67-92.

Buchowski M., 2005 Sacrum i profanum, [w:] Encyklopedia socjologii. Suplement, red. W. Kwaśniewicz, Warszawa.

Connerton P.,

2014 Siedem rodzajów zapomnienia, [w:] (Kon)teksty pamięci. Antologia, red. K. Kończal, Warszawa, s. 343-358.

Stachowski A.H. (red.), 2000 Encyklopedia Krakowa, Warszawa.

Górka Z.,

2009 Ulica Grodzka jako jedna z głównych ulic krakowskiej dzielnicy staromiejskiej, [w:] Gospodarka i przestrzeń: Prace dedykowane Profesor Danucie Ptaszyckiej-Jackowskiej, red. B. Domański, W. Kurek, Kraków, s. 113-122.

Harrison R.,

2013 Heritage. Critical Approaches, London-New York.

Jałowiecki B.,

2009 Magia miejsc, [w:] Fenomen Genius Loci. Tożsamość miejsca w kontekście historycznym i współczesnym, red. B. Gutowski, Warszawa, s. 9-14.

Kowalski K.,

2013 O istocie dziedzictwa europejskiego. Rozważania, Kraków.

Meyer B., Witte de M.,

2013 Heritage and the Sacred: Introduction, „Special Issue of Material Religion: The Journal of Objects, Art and Belief", 9 (3), s. 274-280.

Murzyn M.A.,

2006 Kazimierz. Środkowoeuropejskie doświadczenie rewitalizacji, Kraków.

Murzyn-Kupisz M.A., Purchla J. (red.),

2008 Przywracanie pamięci. Rewitalizacja zabytkowych dzielnic żydowskich w miastach Europy Srodkowej, Kraków.

Niedźwiedź A., 2007 Krakowskie Podgórze - dziedzictwo odkrywane, [w:] Miasto po obu stronach rzeki. Różne oblicza kultury, red. A. Stawarz, Warszawa, s. 187-200.

Nora P.,

2009 Między pamięcia i historią: Les Lieux de Memoire, przeł. P. Mościcki, „Tytuł roboczy: Archiwum \#2", s. 4-12.

Pagacz-Moczarska R.,

2012 W imię przyszłych pokoleń Polaków, „Alma Mater”, 157, s. 56-57.

Purchla J.,

2005 Dziedzictwo a transformacja, Kraków.

Purchla J., Skotnicki A.B., 2007 Przywrócić pamięć = Restoring Memory, [w:] Świat przed katastrofa: Żydzi krakowscy $w$ dwudziestoleciu międzywojennym = A World before a Catastrophe: Krakow's Jews between the Wars, red. nauk. J.M. Małecki, Kraków, s. 5-7.

Sather-Wagstaff J.,

2015 Heritage and Memory, [w:] The Palgrave Handbook of Contemporary Heritage Research, eds. E. Waterton, S. Watson, Basingstoke, s. 191-204. 
Stachowski H., 2000 Encyklopedia Krakowa, Warszawa-Kraków, s. 30, 124-125, 167, 262, 692-693.

Widacka A., 2006 Zagłada modlitewni Tignera, „Kraków”, nr 2 (16).

Wystawa Mapy miasta. Dziedzictwa i sacrum w przestrzeni Krakowa, kurator i koncepcja wystawy: Anna Niedźwiedź; asystent kuratora: Kaja Kajder; scenariusz: Anna Niedźwiedź, Monika Golonka-Czajkowska, Kaja Kajder, Magdalena Kwiecińska; scenografia: Malwina Antoniszczak, Sabina Antoniszczak, Monika Bielak. Wystawa zrealizowana przez polski zespół międzynarodowego konsorcjum HERILIGION we współpracy z Fundacją Tygodnika Powszechnego oraz Muzeum Etnograficznym im. S. Udzieli w Krakowie, w ramach programu HERA Uses of the Past. Wystawa dostępna dla publiczności w okresie: 18 listopada 2017-18 lutego 2018, Muzeum Etnograficzne w Krakowie, ul. Krakowska 46. 